\title{
Origin and transport of larvae of the sea urchin Evechinus chloroticus (Echinodermata: Echinoidea) in a New Zealand fiord
}

\author{
Miles D. Lamare* \\ Portobello Marine Laboratory, Department of Marine Science, University of Otago, PO Box 56, Dunedin, New Zealand
}

\begin{abstract}
Larval transport was investigated in a New Zealand fiord by examining the reproductive cycles and larval distributions of the sea urchin Evechinus chloroticus Valenciennes, and the hydrography in Doubtful Sound over 2 sampling periods (SP). These were from 27 September 1993 to 24 March 1994 (SP1993/94) and 27 October 1994 to 11 May 1995 (SP1994/95). Reproductive cycles of E. chloroticus were monitored at 2 -weekly or monthly intervals in 3 populations in the fiord, while the transport and development of larvae were examined by plankton sampling every $2 \mathrm{wk}$ at 4 permanent stations inside the fiord, and 1 permanent station outside. To determine water exchange in Doubtful Sound, an S4 current meter was deployed at the entrance of the fiord at $15 \mathrm{~m}$ depth. The fiord has an estuarine circulation pattern with a thin low salinity surface layer flowing seaward, below which is a compensatory landward flow of seawater. A major, synchronous spawning of $E$. chloroticus was observed during SP1993/94 which produced a widespread, single cohort of larvae throughout the fiord. In SP1994/95, spawning was fractional and asynchronous and resulted in 2 cohorts of larvae during the summer. Larval densities were an order of magnitude higher during SP1993/94 (2743.0 larvae tow ${ }^{-1}$ ) than in SP1994/95 (155.3 larvae tow ${ }^{-1}$ ). E. chloroticus larval distribution patterns indicate that there was a high level of larval retention within the fiord, consistent with the estuarine circulation pattern. During SP1993/94, average larval densities $4 \mathrm{wk}$ after spawning ranged from 65.3 to 461.0 larvae to ${ }^{-1}$ within the fiord, compared to an average of 2.0 larvae tow ${ }^{-1}$ at the outer site. Similarly, during SP1994/95 larval densities were consistently higher within Doubtful Sound than at the outer site. Larvae completed development within 4 to $6 \mathrm{wk}$ in Doubtful Sound. These results suggest that recruitment of $E$. chloroticus in Doubtful Sound is by larvae that have originated, been retained and completed development within the fiord. Reduced larval exchange provides a mechanism for observed genetic differentiation of this population.
\end{abstract}

KEY WORDS: Echinoid - Sea urchin - Larval transport - Closed population - Recruitment - Estuarine circulation - Fiord Larval biology Evechinus chloroticus

\section{INTRODUCTION}

The relationship between the transport of larval stages and hydrodynamic processes has been investigated for many benthic marine invertebrate species (see reviews by Young \& Chia 1987. Shanks 1995). A direct relationship between the 2 commonly exists, with the resulting dispersal and/or concentration of larvae influencing recruitment dynamics, genetic homogeneity and migration in marine invertebrate

\footnotetext{
- Present address: Friday Harbor Laboratories, University of Washington, Friday Harbor, Washington 98250, USA.

E-mail: miles.lamare@stonebow.otago.ac.nz
}

populations (see reviews by Strathmann 1974, Scheltema 1986, Young \& Chia 1987, Palumbi 1995).

Examples of these processes have been presented for a number of echinoid species. A positive relationship between recruitment and the shoreward transport of larvae has been shown in Dendraster excentricus (Cameron \& Rumrill 1982), while larvae of populations of the same species inhabiting a small fiord were found to be advected offshore by wind-driven circulation (Emlet 1986). Pedrotti \& Fenaux (1992) found that dispersal of echinoid larvae within the Ligurian Sea was closely related to the presence of a coastal divergence zone. When present, the divergence zone acted as a barrier to larval transport and larvae were retained 
close to shore in local eddies. Absence of the divergence resulted in advection of larvae offshore. In the Oregon upwelling zone, Miller \& Emlet (1997) found that alongshore transport of Strongylocentrotus franciscanus and S. purpuratus larvae was associated with winter and summer flow regimes, while the final delivery of larvae to the coast resulted from wind-forced Ekman transport of water onshore.

Other studies have investigated transport of echinoid larvae indirectly. Ebert \& Russell (1988) correlated poor recruitment in populations of Strongylocentrotus purpuratus along the Oregon and Californian coasts with advection of larvae offshore by upwelling and cold water plumes. Ebert et al. (1994) monitored settlement of S. franciscanus and S. purpuratus and found that settlement rates were higher and showed less interannual variation in southern sites compared with northern California. These settlement patterns were consistent with nearshore retention of waters off southern California and offshore advection in northern California. Wing et al. (1995) examined the transport of larvae of the same species in the northern California upwelling system, where settlement was episodic over the season of investigation, and a main settlement event associated with an unusual relaxation of coastal upwelling.

The retention of invertebrate larvae in fiord environments is of particular interest as net transport of water is seaward (Young \& Chia 1987). Net transport in fiords is influenced by fiord geomorphology (Aksnes et al. 1989), adjacent coastal upwelling and downwelling (Kaartvedt \& Svendsen 1995), wind flux (Kaartvedt \& Svendsen 1995), and degree of runoff (Ketchum 1983). Fiords that have a shallow sill at their entrance typically have an estuarine circulation pattern, with the relatively low salinity surface waters flowing seaward, below which is a compensatory, countercurrent flow of seawater into the fiord. Water exchange in the deep water basins behind the sill is intermittent. A result of the pattern of circulation and the physical restrictions of a narrow entrance is that there may be a significant retention and advection of larvae into the fiord at intermediate depths (Young \& Chia 1987). Such advection and retention has been demonstrated for larvae of a number of invertebrate species (e.g. Epifanio et al. 1988, Aksnes et al. 1989, Kaartvedt \& Svendsen 1995, Petersen \& Svane 1995), and has been suggested as the cause of the relatively high species diversity in fiord environs (Pearson 1970, Gage 1972, Rasmussen 1.973).

The sea urchin Evechinus chloroticus Valenciennes is abundant in coastal waters around the New Zealand mainland and offshore islands (McRae 1959, Fell 1960, Pawson 1965, Dix 1970a). Larvae of E. chloroticus occur in the water column from November through to April (Dix 1970b, Walker 1982) and reach competency as early as 3 wk in the laboratory (Dix 1969, Walker 1984) and between 3 and 6 wk within Doubtful Sound (Lamare 1997). A previous study on genetic differentiation in this species has shown that little variation occurs among populations, even over distances of $2200 \mathrm{~km}$ (Mladenov et al. 1997). One exception was the Doubtful Sound population, which was genetically differentiated from the other populations studied. These findings indicate that while gene flow, and hence larval exchange, is high among most populations, there is evidence of restricted larval exchange in the Doubtful Sound population.

This study examines the distribution and transport of Evechinus chloroticus larvae in Doubtful Sound. The horizontal distributions of larvae were examined over 2 consecutive spawning seasons (years), and vertical distributions examined in the second spawning period. Changes in the abundance and distribution of larvae over time are compared with E. chloroticus reproduction and with hydrographical processes occurring within Doubtful Sound.

\section{METHODS}

Study site. Doubtful Sound $\left(45^{\circ} 18^{\prime} 00^{\prime \prime} \mathrm{S}, 166^{\circ} 58^{\prime} 45^{\prime \prime} \mathrm{E}\right)$ is one of a series of fiords indenting the southwestern coast of South Island, New Zealand (Fig. 1). The fiord is approximately $110 \mathrm{~km}$ long in total and $2 \mathrm{~km}$ wide with a $40 \mathrm{~km}$ main channel and 5 secondary arms. Depths within the fiord are relatively great, with a number of basins deeper than $300 \mathrm{~m}$. The fiord has 2 openings to the ocean, the primary entrance (Doubtful Sound) being $\sim 2 \mathrm{~km}$ wide and the second (Thompson Sound) $\sim 1 \mathrm{~km}$ wide. Shallow sills are present at both entrances, where depths range from 0 to $\sim 100 \mathrm{~m}$.

Doubtful Sound has a large input of freshwater, with an average rainfall of $465 \mathrm{~mm} \mathrm{mo}^{-1}$, an annual riverine input of $135 \mathrm{~m}^{3} \mathrm{~s}^{-1}$ and an annual anthropogenic input from the Manapouri Hydroelectric Power Station of $350 \mathrm{~m}^{3} \mathrm{~s}^{-1}$ (Bowman \& Dietrich 1995). The freshwater input results in a thin low salinity surface layer (LSL) throughout the fiord, which has typical salinities of 5 to $10 \%$ and varies in thickness spatially and temporally from 0 to $12 \mathrm{~m}$. The seaward movement of the LSL drives a compensatory flow of deeper seawater into the fiord, resulting in an estuarine circulation pattern. Tidal cycles are semi-diurnal with a maximum vertical range of $1.4 \mathrm{~m}$. Sea temperatures at $10 \mathrm{~m}$ depth typically range from 9 to $17^{\circ} \mathrm{C}$ annually.

Evechinus chloroticus occurs throughout Doubtful Sound, at depths immediately below the LSL to a maximum of $20 \mathrm{~m}$. Mean densities in this depth range are $\sim 0.4 \mathrm{~m}^{-2}$ at the head of the fiord, increasing to $-2.5 \mathrm{~m}^{-2}$ near the entrance. 
Reproductive cycles. Changes in the gonad index of Evechinus chloroticus were examined in 3 Doubtful Sound populations (Fig. 1), Causet Cove (RS-1), Espinosa Point (RS-2) and Deep Cove (RS-3), over 2 sampling periods during the austral spring and summer months. Between 27 September 1993 and 28 March 1994 (referred to hereafter as SP1993/94), 20 individuals were sampled at monthly intervals. For the second sampling period, between 27 October 1994 and 27 April 1995 (referred to hereafter as SP1994/95), 10 individuals were sampled at 2-weekly intervals. For each individual, the drained wet weight (drained of perivisceral fluid) ( $\mathrm{g}$ ) and total gonad wet weight ( $g$ ) were measured. A gonad index $(\%)$ was calculated using the equation

gonad index $(\%)=$

$$
\frac{\text { total gonad weight }(\mathrm{g})}{\text { total drained wet weight }(\mathrm{g})} \times 100
$$

Additional information on the timing of Evechinus chloroticus spawning in Doubtful Sound was obtained from histological examination of gametogenesis (data not presented in this paper), and in situ observations made by SCUBA divers (Lamare 1997).

Plankton sampling. Plankton samples were taken at 5 sites (PS-1 to PS-5) located along a transect running from the head of Doubtful Sound to the entrance (Fig. 1A). The sites were approximately equidistant, with PS-2 to PS-5 representing inner-fiord samples, while the first site (PS-1: Shelter Islands) was situated beyond the sill. While this site is approximately $1 \mathrm{~km}$ from the fiord entrance, it is seaward of the sill and was taken as representative of the open coast plankton (Fig. 1B).

The horizontal distribution of larvae was examined over 2 consecutive years. The first sampling period was between February and April of 1994 (referred to hereafter as SP1993/94), the second between December 1994 and May 1995 (referred to hereafter as SP1994/95). Samples were taken at approximately 2-weekly intervals in both SP1993/94 (3 February, 14 February, 27 February, 15 March and 24 March 1994) and SP1994/95 (14 December 1994 and 17 January, 9 February, 23 February, 7 March, 5 April,

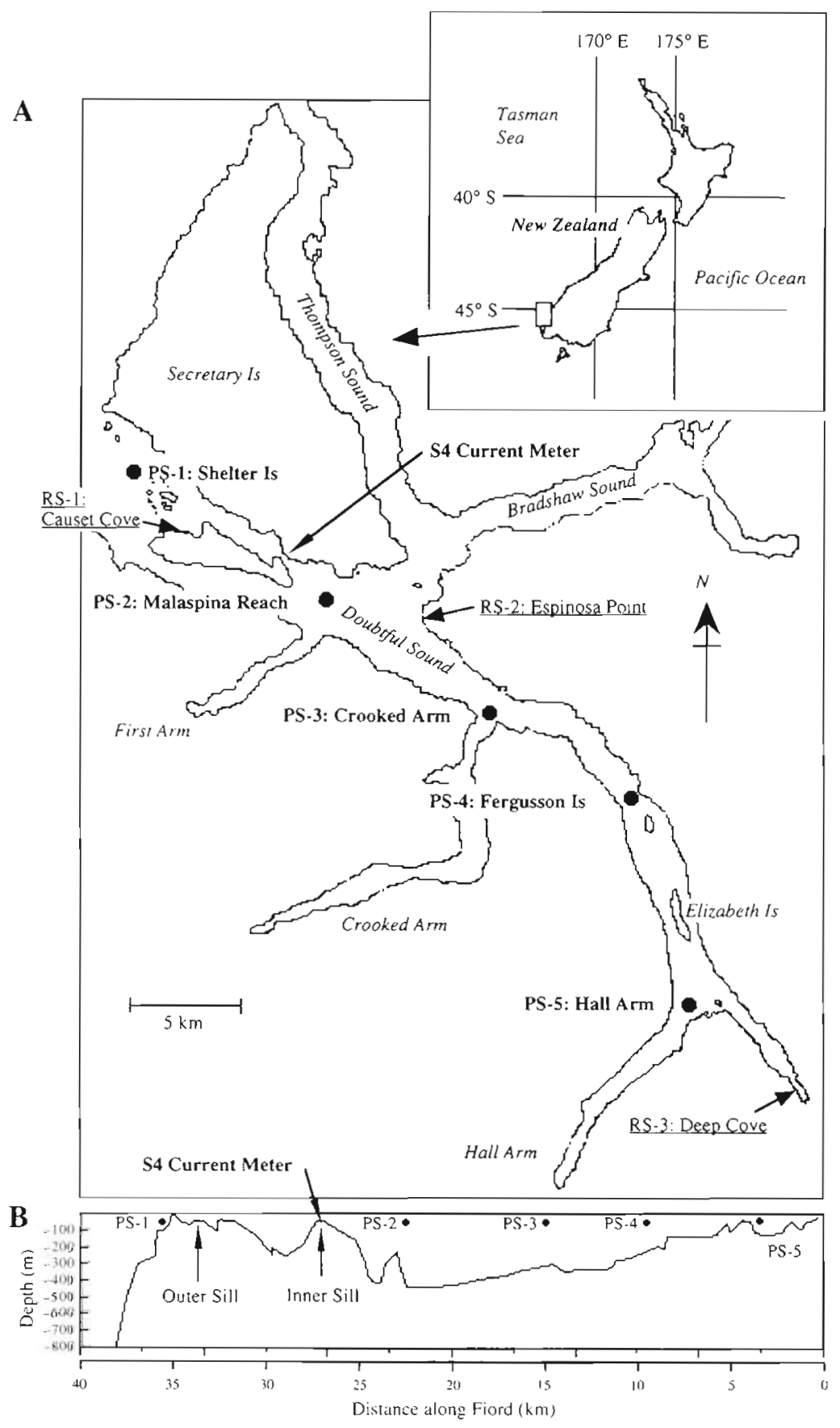

Fig. 1. (A) Location of the 5 plankton sampling sites (PS-1 to PS-5) and the 3 reproduction sampling sites (RS-1 to RS-3) within Doubtful Sound. (B) Cross section of the fiord with the location of sites with respect to the 2 sills present. The location of the S4 current meter deployment site on the inner sill is indicated

27 April and 11 May 1995). On the first 2 sampling dates (3 February and 14 February 1994) 2 duplicate $100 \mathrm{~m}$ vertical hauls were taken. For the remaining 11 sampling dates, 3 replicate $100 \mathrm{~m}$ vertical hauls were taken. For each tow, a $100 \mu \mathrm{m}$ mesh UNESCO WP2 (UNESCO 1968) plankton net with a $50 \mathrm{~cm}$ diameter 
opening was hauled vertically at a rate of $30 \mathrm{~cm} \mathrm{~s}^{-1}$. All samples were preserved in $4 \%$ buffered formalin.

The vertical distribution of Evechinus chloroticus larvae within the water column was examined at PS-4 (Malaspina Reach) on 14 December 1994, 17 January 1995 and 9 February 1995. Sampling during the previous spawning season had shown this site to have high densities of E. chloroticus larvae. Sampling was carried out between 09:00 and 11:00 h on each sampling date. Six depth strata were sampled, 100 to 50,50 to 30,30 to 20,20 to $10,10 \mathrm{~m}$ to the $33 \%$ isohaline (taken as demarcating the bottom of the LSL), and from the LSL halocline to the sea surface. Three replicate samples were taken for each depth stratum, using an automatically closing $100 \mu \mathrm{m}$ mesh UNESCO WP2 plankton net with a $50 \mathrm{~cm}$ diameter opening. The net was hauled vertically at a rate of $30 \mathrm{~cm} \mathrm{~s}^{-1}$, and all samples were immediately preserved in $4 \%$ buffered formalin.

Immediately prior to sampling the vertical distribution of larvae, the depth of the LSL halocline was located by recording sea temperature, dissolved oxygen and salinity profiles. Seawater temperatures and dissolved oxygen concentrations were recorded from the surface down to $50 \mathrm{~m}$ depth using a Yeo+Kal Model 603 Dissolved Oxygen/Temperature Meter, while salinities were recorded from the surface down to $20 \mathrm{~m}$ depth using a Yeo+Kal Model 605 Inductive Salinity Dip Meter. Measurements were made at $50 \mathrm{~cm}$ depth intervals.

Measurements of chlorophyll a concentration (mg $\mathrm{m}^{-3}$ ) were taken at depths of $1 \mathrm{~m}$ (within the LSL), 10 , 20,50 and $100 \mathrm{~m}$ on each sampling date. Two litre water samples were taken at each depth and the concentration of chlorophyll a was determined spectrophotometrically (Strickland \& Parsons 1972).

Analysis of samples. The UNESCO WP2 plankton net has a mean catch efficiency of $94 \%$ in oligotrophic water (as in Doubtful Sound) for tows less than 16 min duration (Hernroth 1987). All tows in this study were less than 6 min duration and were assumed to have a catch efficiency of $100 \%$. Samples were sorted using a dissecting binocular microscope and Bogorov counting dish, with larger samples halved using a Folsom plankton splitter. Evechinus chloroticus larvae recovered from the field were positively identified by comparison with laboratory reared $E$. chloroticus larvae and with larvae of the Pseudechinus genus (the only 2 genera of sea urchins recorded from Doubtful Sound). The number of larvae in each sample was counted, and each larva classified according to the stage of development into 1 of 10 development stages (Table 1).

Hydrographical data. The direction and magnitude of water movement over the inner sill of Doubtful Sound (Fig, 1) were examined using an S4 current meter moored at a depth of $15 \mathrm{~m}$ (earlier plankton samples indicate that $15 \mathrm{~m}$ was the depth of maximum
Table 1. Classification of Evechinus chloroticus larval developmental stages

\begin{tabular}{|c|c|}
\hline $\begin{array}{l}\text { Developmental } \\
\text { stage }\end{array}$ & Notes \\
\hline Blastula & No larval arms present \\
\hline Early 4-armed & $\begin{array}{l}\text { Postoral and anterolateral arms present } \\
\text { but neither at full length }\end{array}$ \\
\hline 4 -armed & $\begin{array}{l}\text { Both postoral and anterolateral arms fully } \\
\text { formed. Gut obvious }\end{array}$ \\
\hline Late 4-armed & 'Bud' postdorsal arms obvious \\
\hline Early 6-armed & Postdorsal arms partially formed \\
\hline 6-armed & $\begin{array}{l}\text { Postoral, anterolateral and postdorsal } \\
\text { arms fully formed }\end{array}$ \\
\hline Early 8-armed & Early development of preoral arms \\
\hline 8-armed & $\begin{array}{l}\text { Postoral, anterolateral, postdorsal and } \\
\text { preoral arms fully formed }\end{array}$ \\
\hline $\begin{array}{l}8 \text {-armed } \\
\text { (rudiment) }\end{array}$ & $\begin{array}{l}\text { Rudiment obvious but no sign of either } \\
\text { tube feet or pedicellaria }\end{array}$ \\
\hline $\begin{array}{l}8 \text {-armed } \\
\text { (competent) }\end{array}$ & $\begin{array}{l}\text { Tube feet and/or pedicellaria visible } \\
\text { protruding from the larval body }\end{array}$ \\
\hline
\end{tabular}

density of Evechinus chloroticus larvae). Measurements were made every 2 min for a $37 \mathrm{~d}$ period between 15 March and 23 April 1995. Later, data were converted to current speeds in the north/south and east/west direction, and an hourly and 12-hourly average calculated over each sampling period to remove tidal residuals. Freshwater discharge rates in Doubtful Sound from the Manapouri Hydroelectric Power Plant for the period 15 March to 23 April 1995 were supplied by Electricity Corporation New Zealand. Hourly wind speed and direction data in Doubtful Sound during the periods 25 January 1994 to 25 March 1995 and 15 March to 23 April 1995 were supplied by the New Zealand National Institute of Water and Atmospheric Research. These wind data were converted to speeds in the north/south and east/west direction.

To examine the relationship between wind and water flow, wind speed data were transformed to wind stress using the equation

$$
\tau=C_{D} P_{d} U^{2}
$$

where $\tau=$ wind stress, $P_{a}=$ density of air and $U=$ wind speed $\left(\mathrm{m} \mathrm{s}^{-1}\right)$. For $1<U<15 \mathrm{~m} \mathrm{~s}^{-1}, C_{D}=0.5 \sqrt{U} \times 10^{-3}$, and for $U \geq 15 \mathrm{~m} \mathrm{~s}^{-1}, C_{D}=2.6 \times 10^{-3}$. Cross-correlation analysis was used to calculate the coefficient of variation $(R)$, and time lag $(\tau)$ between north/south, east/west wind stress components, with the north/south, east/west water flow components using the equation

$$
R(\tau)=\sum_{t=1}^{N} \frac{\left(x_{t}-\bar{x}\right)\left(y_{t-\tau}-\bar{y}\right)}{N \sigma_{x} \sigma_{y}}
$$

where $x_{i}$ is the time series of wind stress, $y_{t}$ is the time series of current speeds, $t$ is time, $\tau$ is the time lag 
between wind and water movement, $\bar{x}$ and $\bar{y}$ are the means of each time series, $\sigma_{x}$ and $\sigma_{y}$ are the standard deviations of each time series, and $N$ is the length of both time series. To allow for autocorrelation within each time series, tests of the significance of each correlation were made with the standard error $(s)$ of $R(\tau)$ calculated as

$$
s^{2}=\sum_{i=-N}^{N}\left[1-\frac{|i|}{N}\right]\left[R_{X X}(i) R_{Y y}(i)\right]
$$

where $R_{x x}(i)$ and $R_{y y}(i)$ are the autocorrelation coefficients for each time series at time lag $i$ (Kope \& Botsford 1988).

\section{RESULTS}

\section{Reproductive biology}

Spawning times of Evechinus chloroticus in each population were identified from decreases in gonad indices (Fig. 2). During SP1993/94, gonad indices increased to a pre-spawning peak on 3 December 1993, with pre-spawning indices of 20.0, 18.3 and $19.1 \%$ recorded in the Causet Cove (RS-1), Espinosa Point (RS-2) and Deep Cove (RS-3) populations respectively. Spawning occurred between 3 December 1993 and 1 February 1994, with a post-spawning indices of $8.8,9.6$ and $11.2 \%$ recorded in the 3 populations respectively.

During SP1994/95, spawning-related decreases in indices were asynchronous between the Causet Cove, Espinosa Point and Deep Cove populations, and appeared to be partial. In Causet Cove, a pre-spawning maximum of $19.2 \%$ was observed on 19 January 1995 , with decreases of 4.5 and $7.0 \%$ observed from 19 January to 9 February and 23 February to 5 April 1995 respectively. At Espinosa Point, the indices increased over the sampling period, with the only evidence of spawning being a $3.1 \%$ decrease in the gonad index that occurred between 14 December 1994 and 19 January 1995. In Deep Cove a pre-spawning maximum of $13.7 \%$ was observed on 14 December 1994, followed by a $3.6 \%$ decrease over the following month. A second, smaller pre-spawning maximum of $13.6 \%$ was observed on 5 April 1995 which was followed by a $3.3 \%$ decrease over the following $3 \mathrm{wk}$.

\section{Spawning observations}

On 27 January 1994 ( 7 d prior to the first plankton samples) Evechinus chloroticus individuals of both sexes were observed spawning in situ along a $100 \mathrm{~m}$ section of Doubtful Sound (Lamare \& Stewart 1998). These observations were between $17: 30$ and 18:30 h

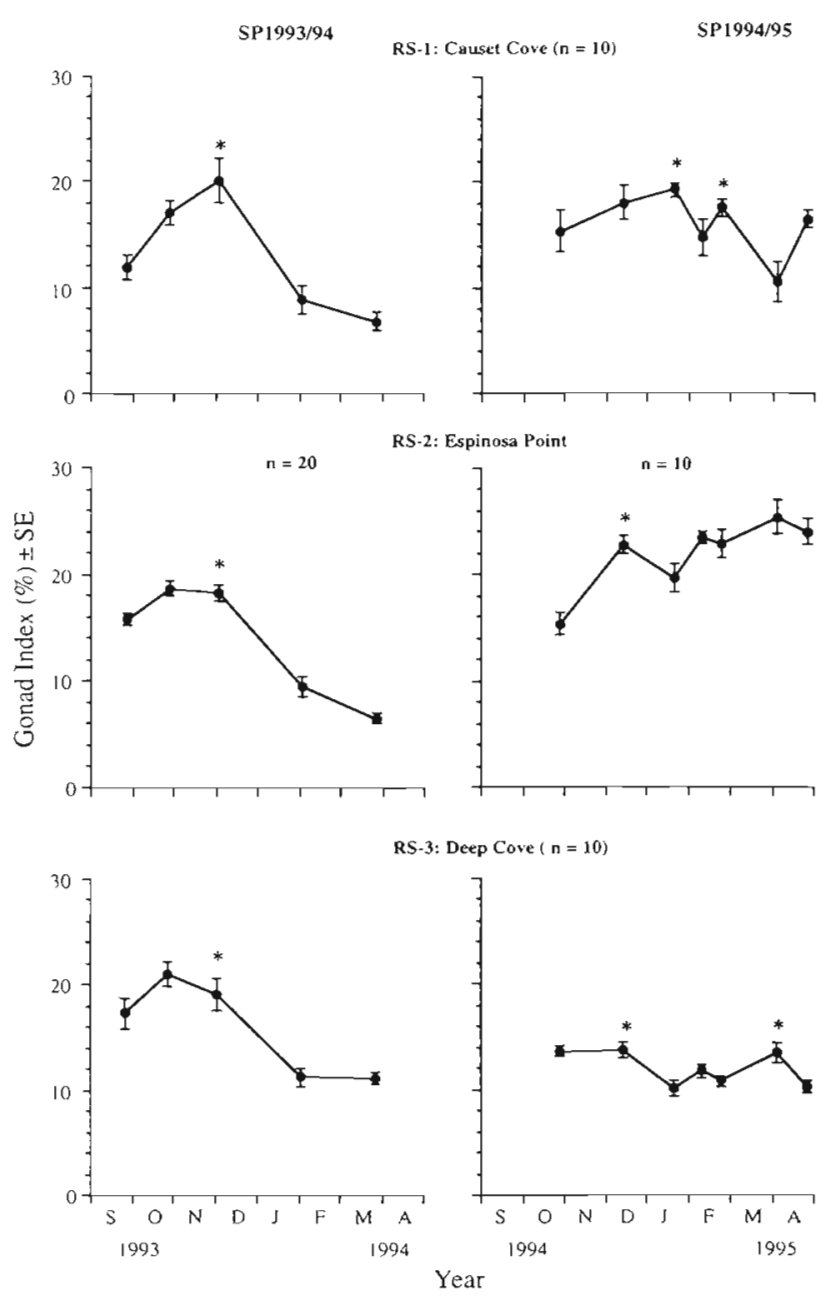

Fig. 2. Changes in the gonad index ( \pm SE) of Evechinus chloroticus from 3 populations in Doubtful Sound between 27 September 1993 and 28 March 1994 (SP1993/94) and between 27 October 1994 and 27 April 1995 (SP1994/95). The commencement of spawning periods based on decreases in gonad index are indicated $(*) . \mathrm{n}=$ number of individuals sampled on each sampling date

( 2 h prior to sunset), with a full moon and spring tide conditions. The sea urchin formed a dense spawning aggregation of both sexes (densities increasing to $20-30 \mathrm{~m}^{-2}$ during spawning), with greater than $90 \%$ of urchins observed spawning at the time. This appeared to be a major event with the water discoloured by the released gametes. No spawning was observed in situ during SP1994/95.

\section{Horizontal distribution of larvae}

Mean number of larvae tow ${ }^{-1}( \pm \mathrm{SE})$ of Evechinus chloroticus (Table 2) and the numbers of larvae in each development stage on each sampling date (Table 3) 
Table 2. Mean number of Evechinus chloroticus larvae $\left( \pm \mathrm{SE}\right.$ ) tow ${ }^{-1}$ at 5 sites within Doubtful Sound over the 2 sampling periods, (A) SP1993/94 (3 February to 24 March 1994) and (B) SP1994/95 (14 December 1994 to 11 May 1995)

\begin{tabular}{|c|c|c|c|c|c|}
\hline Date & PS-1: Shelter Islands & PS-2: Malaspina Reach & PS-3: Crooked Arm & PS-4: Fergusson Island & PS-5: Hall Arm \\
\hline \multicolumn{6}{|l|}{ (A) SP1993/94 } \\
\hline 3 Feb 1994 & $87.5(16.5)$ & $415.5(154.5)$ & $66.0(15.0)$ & $360.0(205.0)$ & $18.0(2.0)$ \\
\hline 14 Feb 1994 & $613.5(280.5)$ & $1729.5(379.5)$ & $2743.0(568.9)$ & $1732.0(280.0)$ & $366.0(51.0)$ \\
\hline 27 Feb 1994 & $2.0(0.6)$ & $65.3(11.3)$ & $105.0(19.5)$ & $146.7(8.5)$ & $461.0(165.9)$ \\
\hline 15 Mar 1994 & $2.0(0.6)$ & $8.5(1.5)$ & $4.0(2.0)$ & $6.0(2.0)$ & $0.3(0.3)$ \\
\hline 24 Mar 1994 & 0.0 & 0.0 & 0.0 & 0.0 & 0.0 \\
\hline \multicolumn{6}{|l|}{ (B) SP1994/95 } \\
\hline 14 Dec 1994 & 0.0 & $41.3(8.4)$ & $119.7(24.7)$ & $155.3(51.6)$ & $12.0(0.6)$ \\
\hline $17 \operatorname{Jan} 1995$ & 0.0 & $1.7(0.3)$ & $1.7(0.3)$ & 0.0 & $4.7(2.0)$ \\
\hline 9 Feb 1995 & 0.0 & 0.0 & 0.0 & 0.0 & 0.0 \\
\hline 23 Feb 1995 & 0.0 & $1.7(1.2)$ & $0.7(0.7)$ & 0.0 & 0.0 \\
\hline 7 Mar 1995 & $0.3(0.3)$ & $2.7(2.7)$ & 0.0 & $0.7(0.3)$ & 0.0 \\
\hline 5 Apr 1995 & 0.0 & $0.3(0.3)$ & $0.3(0.3)$ & 0.0 & 0.0 \\
\hline 27 Apr 1995 & 0.0 & $7.0(1.2)$ & $15.7(0.8)$ & $22.3(4.8)$ & $0.3(0.3)$ \\
\hline 11 May 1995 & 0.0 & 0.0 & 0.0 & 0.0 & 0.0 \\
\hline
\end{tabular}

are given for SP1993/94 and SP1994/95. Horizontal concentrations of larvae are also represented schematically for each sampling period respectively (Figs. 3 \& 4).

SP1993/94 (Tables $2 \& 3$, Fig. 3). Larvae were found at all sampling sites on 3 February 1994 ( 7 d postspawning), both within the fiord and beyond the sill (Fig. 3A). The largest numbers of larvae tow ${ }^{-1}$ (Table 2A) were found at Malaspina Reach (mean no. of lārvae tow $^{-1}=415.5$ ) and Fergusson Island (mean = 360.0) . Lower numbers were found at Shelter Islands (mean = 87.5), with the lowest numbers recorded at Hall Arm (mean $=18.0)$. All samples were dominated by a single cohort of 4-armed larvae (Table 3A). By 14 February, the mean number of larvae to $w^{-1}$ had increased from the previous sampling date (Fig. 3B). Within the fiord,

Table 3. Number and percentage of Evechinus chloroticus larvae in each development stage for all sites pooled within Doubtful Sound on each sampling date during (A) SP1993/94 and (B) SP1994/95. $n=$ total number of larvae sampled on each date

\begin{tabular}{|c|c|c|c|c|c|c|c|}
\hline $\begin{array}{l}\text { (A) SP1993/94 } \\
\text { Stage }\end{array}$ & 3 Feb 1994 & \multicolumn{2}{|c|}{ 14 Feb 1994} & 27 Feb 1994 & \multicolumn{2}{|c|}{15 Mar 1994} & $24 \operatorname{Mar} 1994$ \\
\hline Blastula & 0 & \multicolumn{2}{|c|}{0} & 0 & \multicolumn{2}{|l|}{0} & 0 \\
\hline Early 4A & $91(4.8 \%)$ & \multirow{2}{*}{\multicolumn{2}{|c|}{$\begin{array}{r}14(<0.0 \%) \\
115(0.8 \%)\end{array}$}} & 0 & \multicolumn{2}{|c|}{0} & 0 \\
\hline $4 \mathrm{~A}$ & $1642(86.7 \%)$ & & & $23(0.9 \%)$ & \multicolumn{2}{|c|}{$16(25.8 \%)$} & 0 \\
\hline Late $4 \mathrm{~A}$ & $128(6.8 \%)$ & \multicolumn{2}{|c|}{$14115(98 \%)$} & $94(4.0 \%)$ & \multicolumn{2}{|c|}{$26(41.9 \%)$} & 0 \\
\hline Early $6 \mathrm{~A}$ & $33(1.7 \%)$ & \multicolumn{2}{|c|}{$50(0.3 \%)$} & $164(7.0 \%)$ & \multirow{2}{*}{\multicolumn{2}{|c|}{$\begin{array}{c}10(16.1 \%) \\
0\end{array}$}} & 0 \\
\hline $6 \mathrm{~A}$ & 0 & \multicolumn{2}{|c|}{$25(0.2 \%)$} & $563(24.1 \%)$ & & & 0 \\
\hline Early $8 \mathrm{~A}$ & 0 & \multicolumn{2}{|c|}{$2(<0.0 \%)$} & $228(9.7 \%)$ & \multicolumn{2}{|l|}{0} & 0 \\
\hline $8 \mathrm{~A}$ & 0 & \multicolumn{2}{|c|}{$41(0.3 \%)$} & $594(25.4 \%)$ & \multicolumn{2}{|c|}{$2(3.2 \%)$} & 0 \\
\hline $8 \mathrm{~A}$ rudiment & 0 & \multirow{2}{*}{\multicolumn{2}{|c|}{$\begin{array}{l}9(<0.0 \%) \\
2(<0.0 \%)\end{array}$}} & $479(20.5 \%)$ & \multirow{2}{*}{\multicolumn{2}{|c|}{$\begin{array}{l}7(11.3 \%) \\
1(1.6 \%)\end{array}$}} & 0 \\
\hline $8 \mathrm{~A}$ competent & 0 & & & $195(8.3 \%)$ & & & 0 \\
\hline n & 1894 & \multicolumn{2}{|c|}{14373} & 2340 & \multicolumn{2}{|c|}{62} & 0 \\
\hline \multicolumn{8}{|l|}{ (B) SP1994/95 } \\
\hline Stage & 14 Dec 1994 & $1+\operatorname{Jan} 1995$ & 9 Feb 1995 & 23 reb 1995 & 7 Mar 1995 & 5 Apr 1995 & $2+$ Apr 1995 \\
\hline Blastula & 0 & 0 & 0 & 0 & 0 & 0 & 0 \\
\hline Early $4 \mathrm{~A}$ & $18(1.8 \%)$ & 0 & 0 & 0 & 0 & 0 & 0 \\
\hline $4 \mathrm{~A}$ & $963(97.7 \%)$ & 0 & 0 & 0 & 0 & 0 & $4(2.9 \%)$ \\
\hline Late $4 \mathrm{~A}$ & $5(0.5 \%)$ & $3(12.5 \%)$ & 0 & $7(100.0 \%)$ & $3(27.3 \%)$ & 0 & $45(32.9 \%)$ \\
\hline Early $6 \mathrm{~A}$ & 0 & $4(16.7 \%)$ & 0 & 0 & $6(54.5 \%)$ & 0 & $86[62.8 \%]$ \\
\hline $6 \mathrm{~A}$ & 0 & 0 & 0 & 0 & $2(18.2 \%)$ & 0 & $1(0.7 \%)$ \\
\hline Early $8 \mathrm{~A}$ & 0 & $4(16.7 \%)$ & 0 & 0 & 0 & 0 & $1(0.7 \%)$ \\
\hline $8 \mathrm{~A}$ & 0 & $5(20.8 \%)$ & 0 & 0 & 0 & $1(100.0 \%)$ & 0 \\
\hline $8 \mathrm{~A}$ rudiment & 0 & $8(33.3 \%)$ & 0 & 0 & 0 & 0 & 0 \\
\hline $8 \mathrm{~A}$ competent & 0 & 0 & 0 & 0 & 0 & 0 & 0 \\
\hline $\mathrm{n}$ & 986 & 24 & 0 & 7 & 11 & 1 & 137 \\
\hline
\end{tabular}



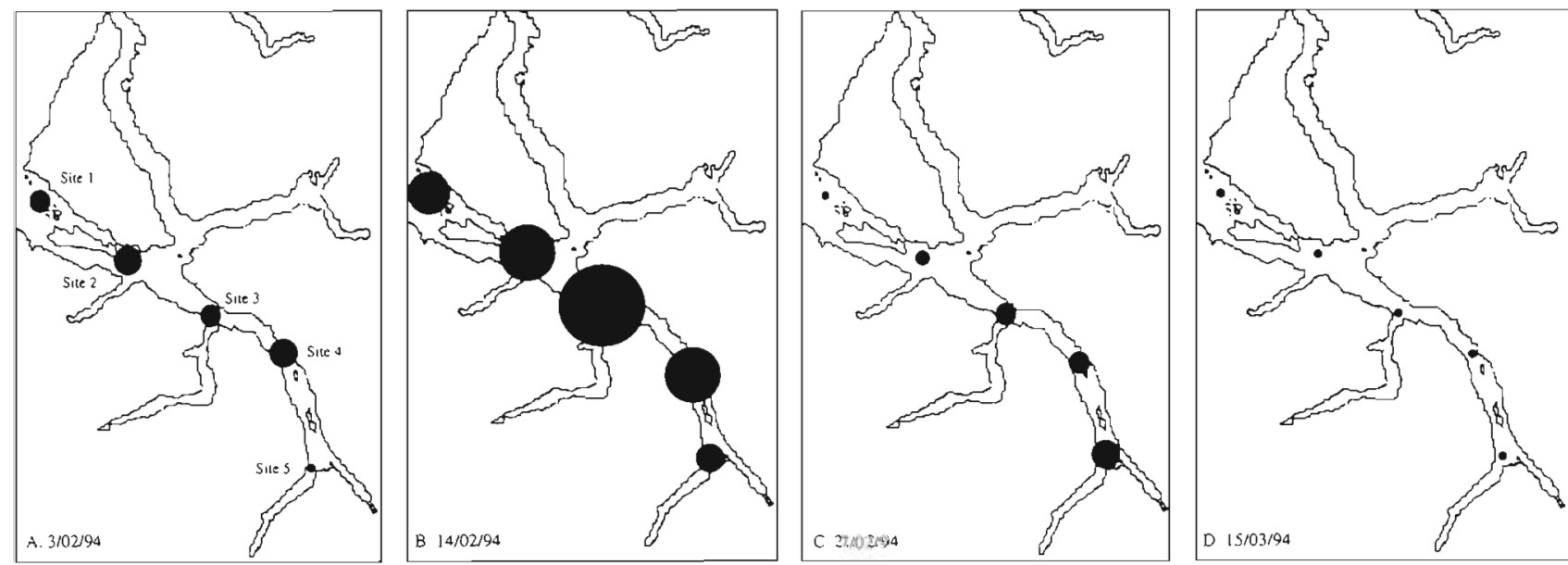

Larval Density
(mean number of
larvae per tow)

$0-50 \quad 50-100 \quad 100-250 \quad 250-500$

$500-1000$

$1000-2000$

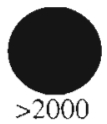

Fig. 3. Distribution of Evechinus chloroticus larvae within Doubtful Sound during the SP1993/94 sampling period (3 February to 15 March 1994). Larval densities are expressed as the mean number of larvae per tow. Note that as there were no larvae present, there is no corresponding map for the 24 March 1994 sample
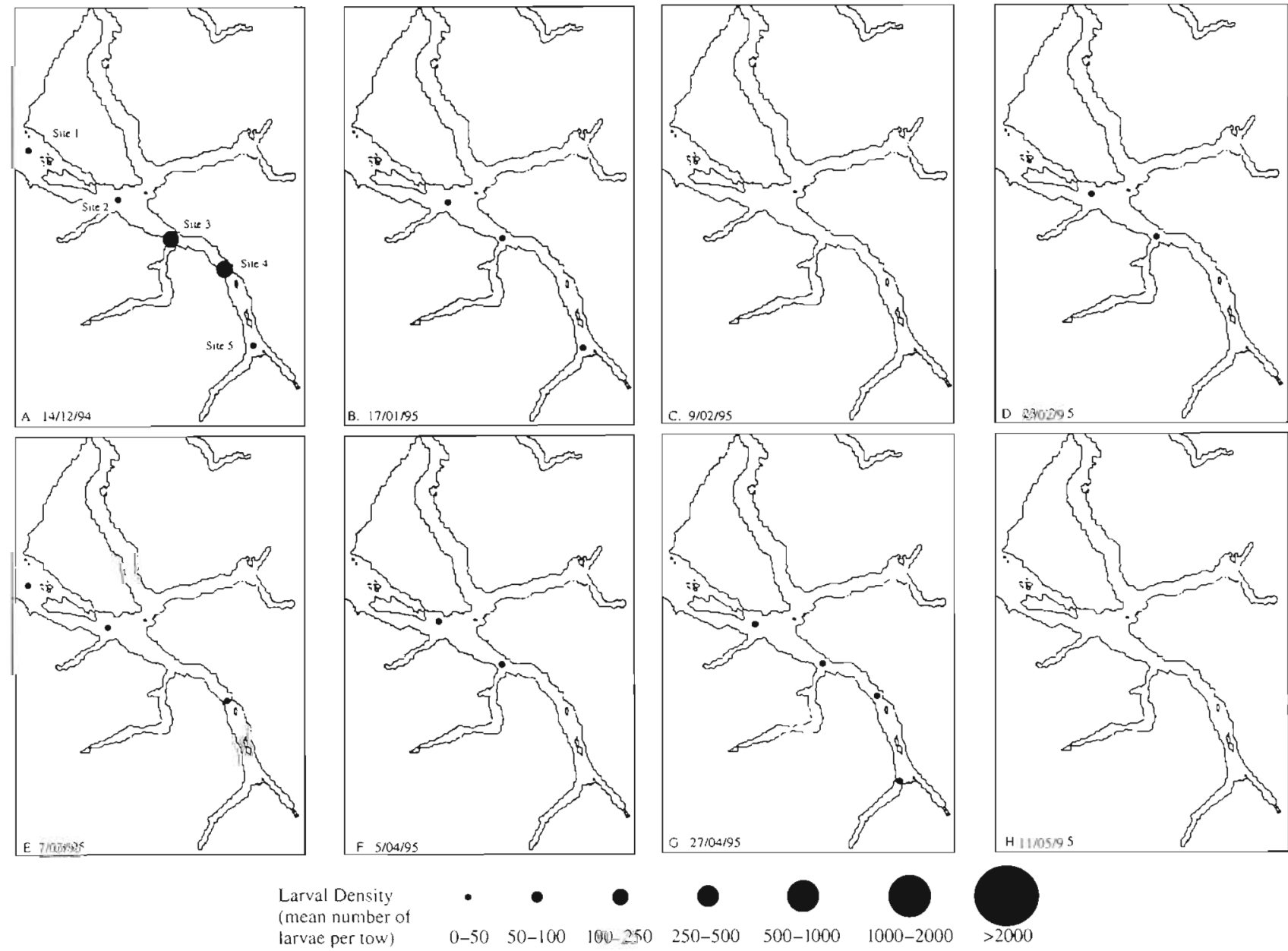

Larval Density
(mean number of larvae per low

$0-50 \quad 50-100 \quad 100-250 \quad 250-500 \quad 500-1000$

$1000-2000>2000$

Fig. 4. Distribution of Evechinus chloroticus larvae within Doubtful Sound during the SP1994/95 sampling period (14 December 1994 to 11 May 1995). Larval densities are expressed as the mean number of larvae per tow 
the greatest increase in larval density was found at Crooked Arm (42-fold increase in mean density from the previous sampling date), while at Hall Arm, Fergusson Island and Malaspina Reach increases were 20-, 5- and 4-fold respectively (Table 2A). Numbers at Shelter Islands tended to be lower than at sites within the fiord $($ mean $=613.5)$. All samples were dominated by a single cohort of late 4 -armed larvae (Table $3 \mathrm{~A}$ ). By 27 February 1994 (Fig. 3C), 2 notable changes in the distribution of larvae had occurred. Firstly, while the 4 outer sites showed a decrease in numbers (Table $2 \mathrm{~A}$ ), the largest decrease in larval densities was observed at Shelter Islands (mean $=2.0$ ). Numbers within the fiord remained comparatively high, ranging from a mean of 461.0 (Hall Arm) to 65.3 (Malaspina Reach). Secondly, the only site to show an increase in larval densities over this period was Hall Arm, where numbers increased 1.3-fold, from a mean of 366.0 to a mean of 461.0. All samples contained a wide range of larval developmental stages (Table 3A). By 15 March 1994 (Fig. 3D), all sites were found to have very low densities of larvae, with numbers ranging from 0.3 to a maximum of 8.5 larvae (Table $2 \mathrm{~A}$ ). No larvae were found at any of the 5 sites on 24 March 1994

Almost no competent Evechinus chloroticus larvae were found in plankton samples taken on 3 and 14 February (18 d post-spawning), but were present on 27 February (31 d post-spawning) (Table 2A). By 15 March (47 d post-spawning), very few larvae were found in the plankton $(<0.27 \%$ of the total number of larvae sampled). These findings indicate that almost all larvae reach competency some time between 18 and $31 \mathrm{~d}$.

SP1994/95 (Tables 2 \& 3, Fig. 4). On 14 December 1994, Evechinus chloroticus larvae were present at all but the Shelter Islands site (Fig. 4A). Densities were highest at Fergusson Island (mean no. of larvae tow ${ }^{-1}=$ 155.3) (Table 2B) and Crooked Arm sites (mean = 119.7). Lower densities were recorded at Malaspina Reach (mean $=41.3$ ) and Hall Arm (mean $=12.0$ ). The larvae sampled on this date represent the first of 2 E. chloroticus larval cohorts sampled during the SP1994/95 sampling period, and were the highest densities of larvae recorded over SP1994/95. Samples were dominated by a single cohort of 4-armed larvae (Table 3B). On 17 January 1995 (Fig 4B) larvae were absent at the Shelter Island and Fergusson Island sites, and present at low numbers at the Hall Arm (mean = 4.7), Crooked Arm (mean =1.7) and Malaspina Reach sites (mean $=1.7$ ) (Table $2 B$ ). These larvae ranged from 4 -armed to 8-armed rudiment stages (Table 3B). A small cohort of well developed larvae (8-armed and 8-armed rudiment) was present at Hall Arm (Table 3B). Between 9 February and 5 April 1995 (Fig. 4C-F) larvae were recorded in low densities throughout the fiord. No larvae were found in Hall Arm during this period, while only 1 larva was recorded in the Shelter Islands samples. A small number of late 4-armed larvae were found at Malaspina Reach (mean = 1.7) and Crooked Arm (mean = 0.7) on 23 February. On the subsequent sampling date ( 7 March) low numbers of late 4 -armed larvae and 6 -armed larvae were present at Malaspina Reach (mean $=2.7$ ) and Fergusson Island (mean $=0.7)$. The second cohort of $E$. chloroticus larvae identified during SP1994/95 was recorded in the 4 inner fiord sites on 27 April 1995 (Fig. 4G), but was absent from the Shelter Islands. Densities of larvae within this cohort were comparatively low (Table 2B), ranging from a mean of 22.3 larvae tow ${ }^{-1}$ (Fergusson Island) to 0.3 (Hall Arm). This cohort was made up of late 4 -armed and early 6-armed larvae (Table 3B). On 11 May 1995 no larvae were recorded (Fig. 4H).

\section{Vertical distribution}

On 14 December 1994 (Fig. 5) Evechinus chloroticus larvae were not found in the low salinity Iayer (LSL), or at depths greater that $30 \mathrm{~m}$. Larvae were present between the LSL halocline $(4.0 \mathrm{~m}$ depth), and $10 \mathrm{~m}$ at a mean density of 3.9 larvae $\mathrm{m}^{-3}$ (mean of 4.7 larvae to $w^{-1}$ ), with the highest densities recorded between 10 and $20 \mathrm{~m}$ depth at an average density of 7.3 larvae $\mathrm{m}^{-3}$ (mean of 14.3 larvae tow ${ }^{-1}$ ). Densities of 4.9 larvae $\mathrm{m}^{-3}$ (9.7 larvae tow ${ }^{-1}$ ) were recorded between 20 and $30 \mathrm{~m}$ depth. The larvae sampled on this date were almost entirely early to late 4 -armed stages, and no depth related differences in the distribution of developmental stages were apparent. One 8-armed larva was recovered between the LSL halocline and the $10 \mathrm{~m}$ depth stratum. A total of 2 larvae were found in the 17 January 1995 and 9 February 1995 samples. For 17 January, one 8-armed larva was found between 50 and $100 \mathrm{~m}$ depth, while one late 4 -armed larva was found between the LSL halocline and $10 \mathrm{~m}$ depth on 9 February.

The relationship between the vertical distributions of larvae and the stratification of the water column was examined for the 14 December 1994 samples (Fig. 5). Larvae were restricted to salinities ranging from 33.0 to $35.0 \%$, being absent in the LSL. Within the LSL, salinities ranged from $7.7 \%$ at the surface to $16.6 \%$ immediately above the halocline ( $3 \mathrm{~m}$ depth). Water temperatures and dissolved oxygen concentrations were highest immediately below the LSL halocline $\left(13.3^{\circ} \mathrm{C}\right.$ and $7.7 \mathrm{mg} \mathrm{l}^{-1}$ respectively). Larvae were associated with water temperatures ranging from 11.6 to $13.3^{\circ} \mathrm{C}$ and oxygen concentrations ranging from 6.4 to $7.7 \mathrm{mg} \mathrm{l}^{-1}$. A small cline in water temperatures at 24 to $26 \mathrm{~m}$ depth and an oxycline between 25 and $30 \mathrm{~m}$ depth coincided with the lower depth limits of larvae 
A. Evechunus chloroticus Larval Densily (no. $\mathrm{m}^{-3}$ )
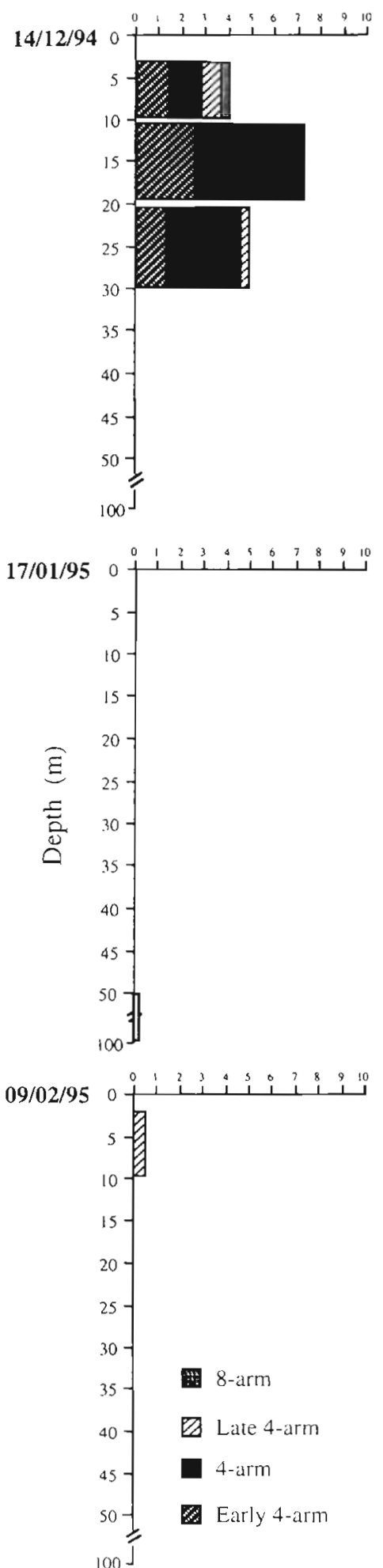

B. Chlorophyll-a Concentration $\left(\mathrm{mg} \mathrm{m}^{-3}\right)$
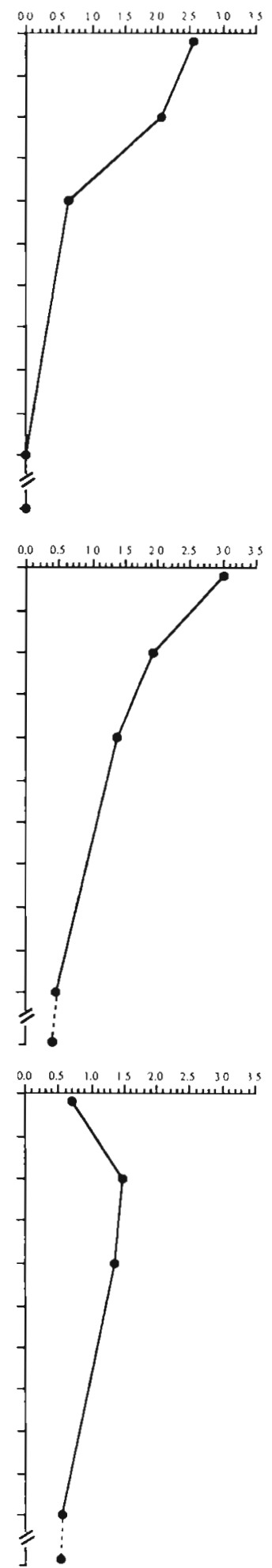

C. Oxygen. Temperature and Salinity profiles
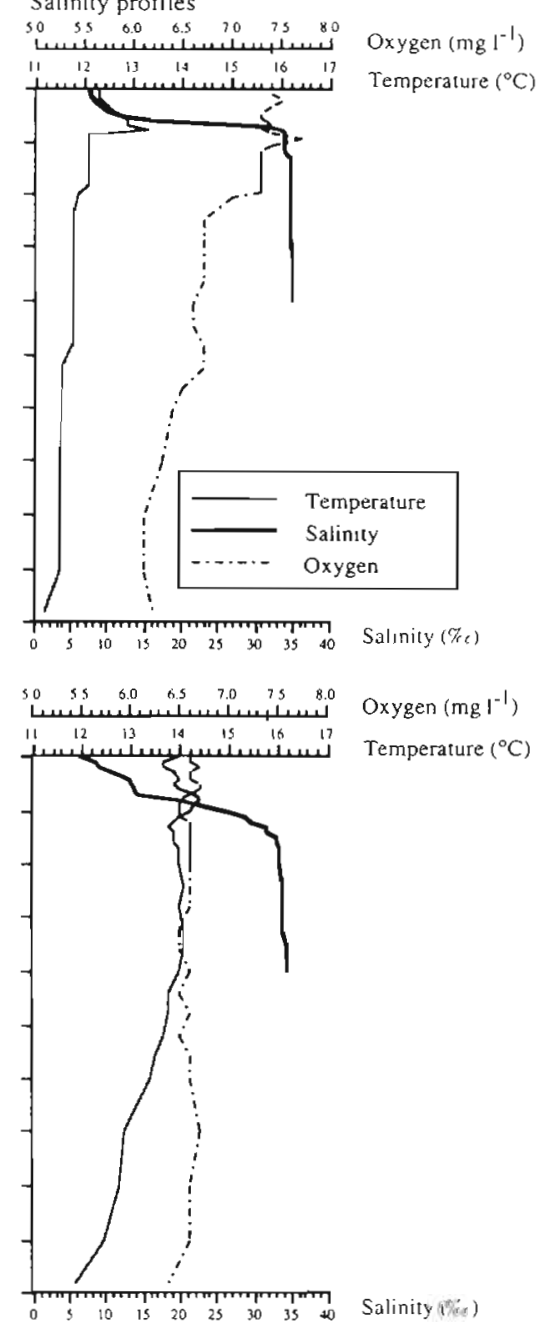

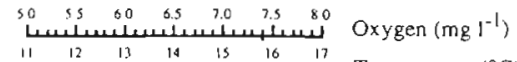

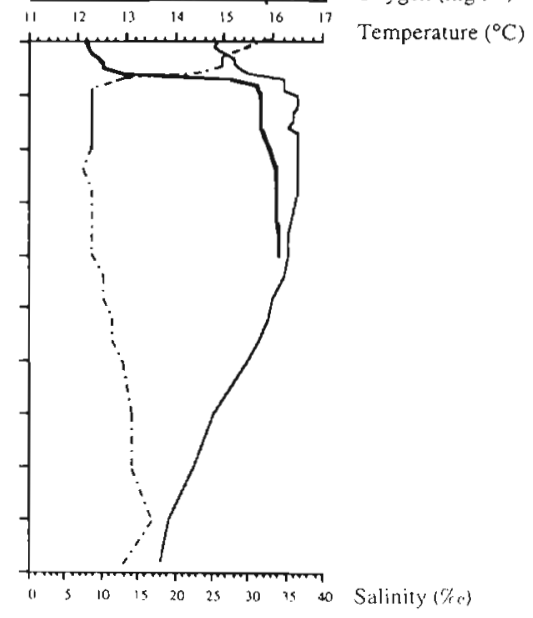

Fig. 5. Vertical density of Evechinus chloroticus larvae (no. $\mathrm{m}^{-3}$ ) between 0 and $100 \mathrm{~m}$ depth at Malaspina Reach on 14 December 1994, 17 January 1995 and 9 February 1995. (A.) The proportion of larvae in each developmental stage is indicated. Note only 4 of the stages were present during the vertical sampling. (B) Depth profiles of chlorophyll a from 0 to $100 \mathrm{~m}$ on each sampling date.

(C) Depth profiles of salinity $(0$ to $20 \mathrm{~m})$, sea temperature $(0$ to $50 \mathrm{~m})$ and oxygen $(0$ to $50 \mathrm{~m})$ for each sampling date 

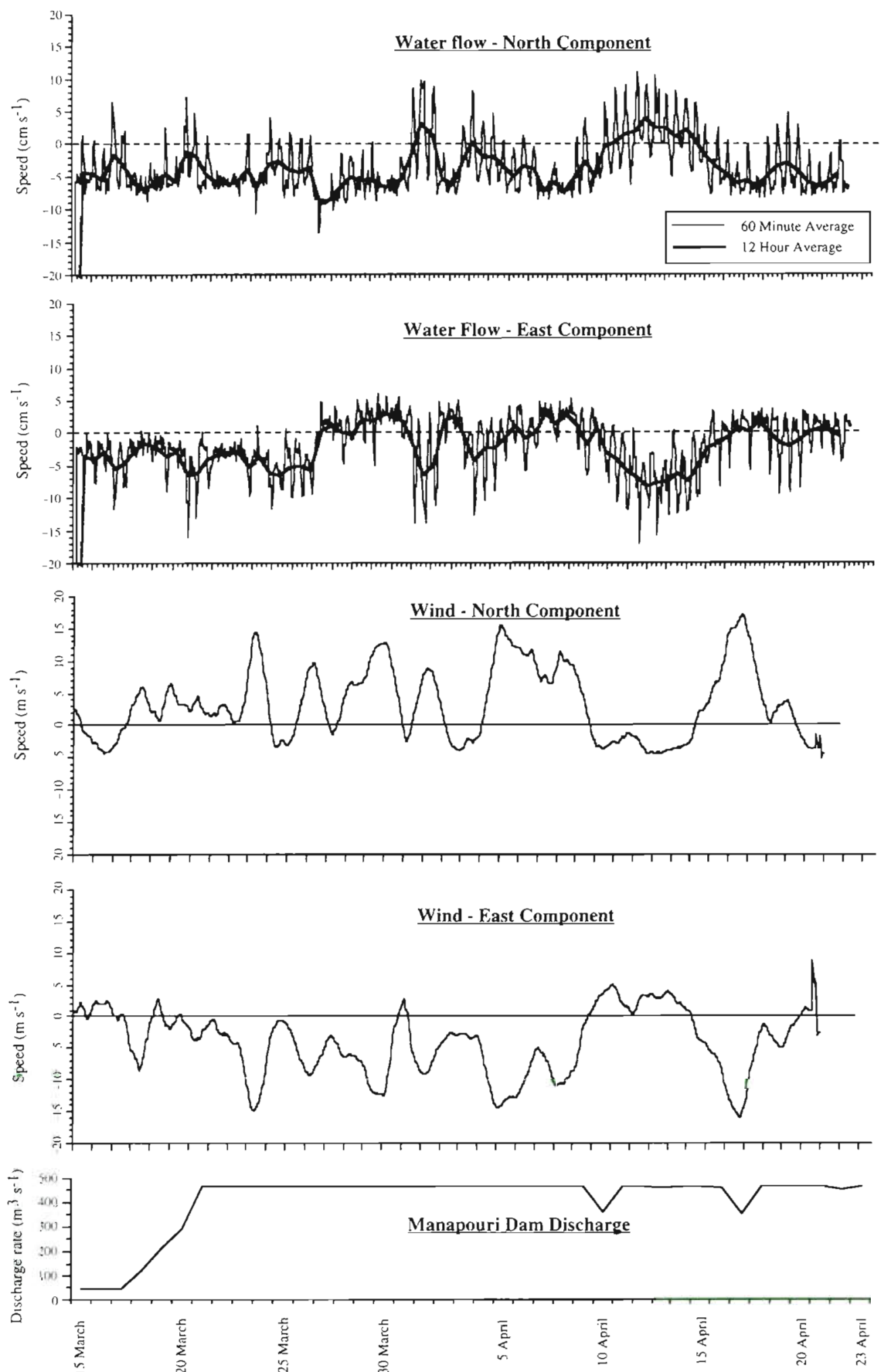

Day (1995)

Fig. 6. S4 current meter recordings of water movement over the inner sill of Doubtful Sound ( $15 \mathrm{~m}$ depth), and wind conditions for Doubtful Sound between 15 March and 23 April 1995. Speeds of the north and east component of water and wind flow over the sampling period are illustrated. Hourly discharge into Doubtful Sound from the Manapouri Power Station region is illustrated for the sampling period 
Table 4. Cross-correlation coefficients $R(\tau)$ between the east/ west and north/south components (time lag) of wind stress and water flow in Doubtful Sound between 15 March and 24 April $1995 .^{\circ} p<0.05$, accounting for autocorrelation within each time series

\begin{tabular}{|llll|}
\hline & N-S wind & E-W wind & N-S current \\
\hline E-W wind & $0.895^{*}(0 \mathrm{~h})$ & & \\
N-S current & $0.520^{\circ}(2 \mathrm{~h})$ & $0.527 \cdot(2 \mathrm{~h})$ & \\
E-W current & $0.597^{*}(1 \mathrm{~h})$ & $0.601^{\circ}(0 \mathrm{~h})$ & $0.760^{*}(0 \mathrm{~h})$ \\
\hline
\end{tabular}

Chlorophyll a concentrations over the 3 sampling dates tended to decrease with depth (Fig. 5). On 14 December, concentrations were highest in the LSL $\left(2.6 \mathrm{mg} \mathrm{m} \mathrm{m}^{-3}\right.$ ), decreasing to $0.0 \mathrm{mg} \mathrm{m}^{-3}$ at $50 \mathrm{~m}$ depth. Maximum larval densities coincided with chlorophyll a concentrations of 1.4 to $1.9 \mathrm{mg} \mathrm{m}^{-3}$, although some larvae were found between 20 and $30 \mathrm{~m}$ depth where concentrations were $<1.4 \mathrm{mg} \mathrm{m}^{-3}$.

\section{Fiord hydrography}

The speed of water movement in the north/south and east/west components and net current speeds at $15 \mathrm{~m}$ depth over the inner sill of Doubtful Sound are illustrated (Fig. 6). A semi-diurnal tidal current oscillation was evident during this period, over-ridden by a residual movement of water into and out of the fiord. Four residual current phases were apparent during this period. Between 15 and 26 March water moved in a southwest direction (out of the fiord) at typical net current speeds of from 5 to $9 \mathrm{~cm} \mathrm{~s}^{-1}$. Between $26 \mathrm{March}$ and 10 April, water movement alternated between periods of inward, southeast flow (26 to 31 March, 2 to 3 April, 5 to 10 April) and periods of southwest, outward flow (31 March to 2 April, 3 to 5 April). A net inward flow of $4.14 \mathrm{~cm} \mathrm{~s}^{-1}$ was recorded over this period. Between 10 and 16 April, a period of northwest, outward water flow was evident, with typical net current speeds of between 6.5 and $9 \mathrm{~cm} \mathrm{~s}^{-1}$ recorded. Finally, between 16 and 24 April, water movement alternated between periods of inward, southeast flow and periods of outward, southwest flow. A net inflow at average speeds of $4.8 \mathrm{~cm} \mathrm{~s}^{-1}$ was recorded over this last phase.

Over this period, there was a large input of freshwater into Doubtful Sound from the Manapouri Power Station. This input was not correlated with change in the direction of water movement in Doubtful Sound (Fig. 6). Discharge increased from $49 \mathrm{~m}^{3} \mathrm{~s}^{-1}$ on 15 March to $464 \mathrm{~m}^{3}$ $\mathrm{s}^{-1}$ on 21 March and, with the exception of a $100 \mathrm{~m}^{3} \mathrm{~s}^{-1}$ dip on 10 and 17 April, remained constant during the rest of the sampling period $\left(\sim 460 \mathrm{~m}^{3} \mathrm{~s}^{-1}\right)$.
In contrast, flow of water within Doubtful Sound appears to be wind driven (Fig. 6). Cross-correlation analyses (Table 4 ) indicate that movement of water in the east/west component was positively correlated with wind stress in the north/south direction $(R=0.597, \tau=$ $1 \mathrm{~h}, \mathrm{p}<0.05$ ) and negatively with wind stress in the east/west direction $(R=0.601, \tau=0 \mathrm{~h}, \mathrm{p}<0.05)$. Water movement in the north/south direction was negatively correlated with wind stress in the north/south direction $(R=0.520, \tau=2 \mathrm{~h}, \mathrm{p}<0.05)$ and positively correlated with wind stress in the east/west direction $(R=0.527, \tau=$ $2 \mathrm{~h}, \mathrm{p}<0.05)$. There was a high cross-correlation within the 2 wind components $(R=0.895, \tau=0 \mathrm{~h}, \mathrm{p}<0.05)$, and within the 2 water flow components $(R=0.760, \tau=0 \mathrm{~h}$. $\mathrm{p}<0.05$ ), and their flows cannot be examined separately (Table 4). In general however, water flows out of the fiord (west direction) during periods of onshore winds (east direction), and into the fiord (east direction) during periods of offshore (west direction) winds

\section{DISCUSSION}

Larval transport in Evechinus chloroticus in Doubtful Sound was investigated though an examination of reproduction, planktonic distributions, and hydrographic processes. The spatial and temporal distribution of larvae differed greatly between sampling seasons. For SP1993/94, a single cohort of larvae was sampled, with numbers peaking on 14 February 1994 (2743 larvae tow $^{-1}$ ). For the corresponding period during SP1994/95, mean larval densities were less than 5 tow $^{-1}$, with the highest densities recorded on 14 December 1994 (155.3 larvae tow ${ }^{-1}$ ) and on 27 April 1995. The maximum density during SP1993/94 was 22 -fold higher than the maximum recorded for SP1994/95.

Differences in the temporal distribution of larvae between the sampling periods can be correlated with interannual differences in the reproductive cycles of Evechinus chloroticus. In SP1993/94, both a synchronous drop in gonad indices in all 3 populations and an observed mass spawning event are consistent with the suggestion that spawning was a major, synchronous event on 27 January. Larval distributions for this year are also consistent with this suggestion, with a single cohort of early 4 -armed larvae (which are 4 to $6 \mathrm{~d}$ old larvae when reared in the laboratory) found throughout Doubtful Sound on 3 February, $7 \mathrm{~d}$ after the observed spawning. No advanced E. chloroticus larvae were found in these first plankton samples, nor was a large cohort of 4-armed larvae found in any of the later plankton samples. This suggests no significant spawning occurred either before or after 27 January. In contrast, spawning in SP1994/95 was asynchronous throughout the fiord, occurred over a longer time 


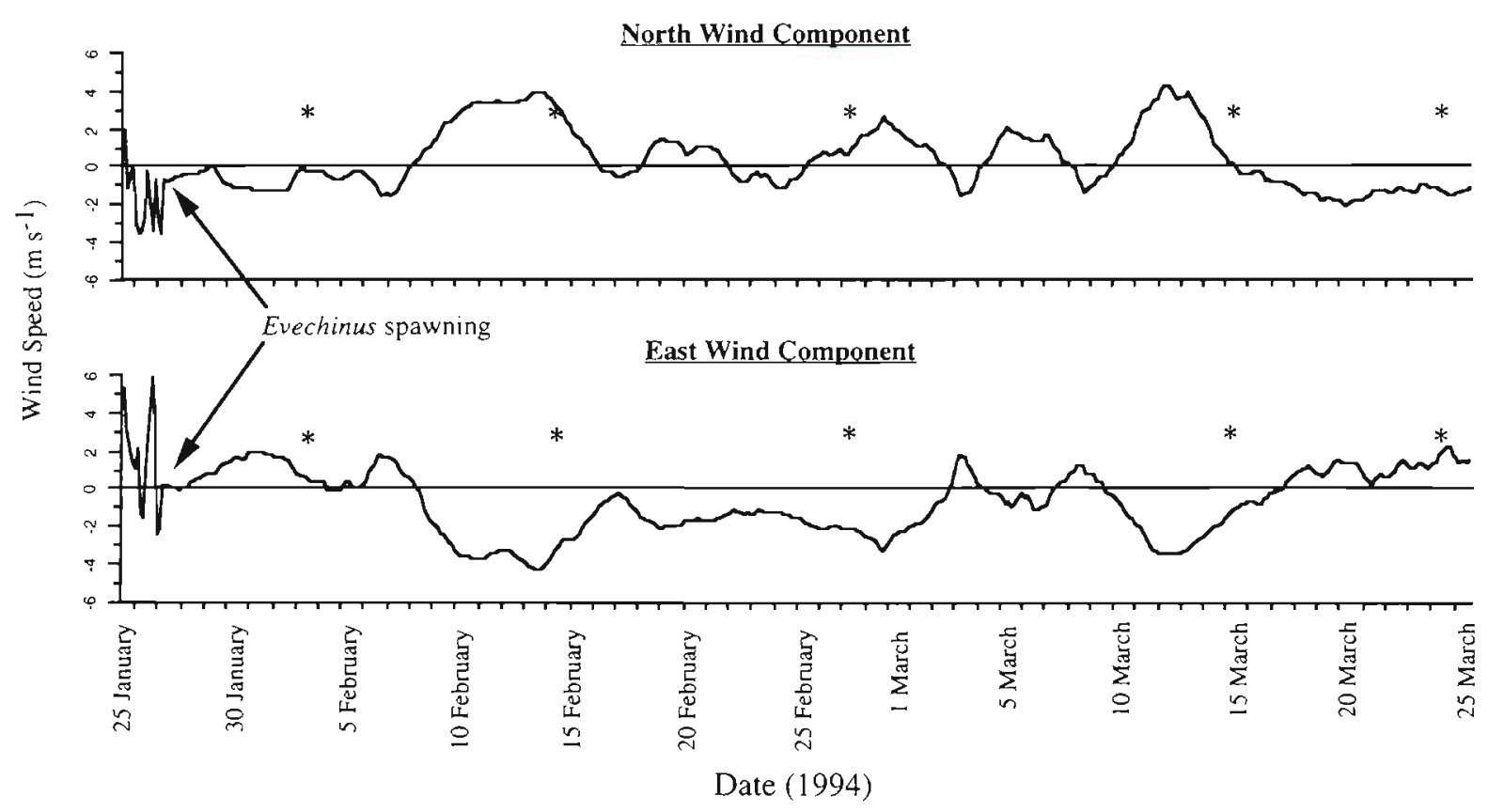

Fig. 7 Wind speeds in the north and east components for the Doubtful Sound region between 25 January and 25 March 1994. The times of the Evechinus chloroticus spawning event and subsequent plankton tows (*) are indicated over this period

period (14 December 1994 to at least 27 April 1995) and appeared intermittent, with possibly 2 spawning episodes. Two cohorts of larvae were present during the season; the first, found on 14 December 1994, corresponded to a 3.1 and $3.6 \%$ decrease in mean gonad indices during December at Espinosa Point and Deep Cove, respectively; the second, found on 27 April 1995 , corresponded with a 7.0 and $3.3 \%$ decrease in mean gonad indices during March and April at Causet Cove and Deep Cove, respectively.

Spatial differences in the distributions of Evechinus chloroticus larvae provide information on the patterns of larval transport in Doubtful Sound. Firstly, densities of larvae were almost always higher at sites within the fiord, compared with samples taken beyond the sill (Shelter Islands). High densities of larvae within the fiord provide good evidence that the larvae sampled during SP1993/94 and SP1994/95 originated from adult E. chloroticus populations within the fiord. The results also suggest that there is a higher rate of larval retention within the fiord compared with the site beyond the sill. This retention was most apparent during SP1993/94, when densities of larvae to ${ }^{-1}$ outside the fiord decreased from 613.5 tow $^{-1}$ on 14 February 1994 to 2.0 tow $^{-1} 13 \mathrm{~d}$ later. Densities within the fiord over the same period remained comparatively high, ranging from 65.3 to 461.0 larvae tow ${ }^{-1}$. Secondly, during SP1993/94 the density of larvae in Hall Arm increased between 14 and 27 February 1994, while all other sites showed a decrease in densities over the same period. This was due to an increase in the numbers of advanced-stage larvae, indicating there was up-fiord transport and accumulation of larvae at this site over time.

The mechanisms of retention and up-fiord transport of larvae in Doubtful Sound can be examined. S4 current meter recordings indicated that at $15 \mathrm{~m}$ depth, water movement over the sill of the fiord was either: (1) a relatively slow, fluctuating flow into and out of the fiord at periodicities of 1 to $3 \mathrm{~d}$, with a net up-fiord flow of water over a period of up to $2 w_{k_{i}}$ or (2) a faster flow out of the fiord for periods of $4 \mathrm{~d}$ to at least $11 \mathrm{~d}$. This movement of water can be correlated with wind forcing. Periods of offshore winds (west direction) correlate with water flowing into the fiord at typical speeds of $-5.0 \mathrm{~cm} \mathrm{~s}^{-1}$ During the period of the S4 deployment, offshore winds were present for $25.5 \%$ of the time, with water flowing into the fiord for $32.9 \%$ of the time. Periods of onshore winds (east direction) correlate with a faster flow of water out of the fiord at typical speeds of $-9.0 \mathrm{~cm} \mathrm{~s}^{-1}$. Onshore winds occurred in Doubtful Sound for $74.5 \%$ of the recording time, with water flowing out of the fiord $67.1 \%$ of the recording time.

To examine inward and outward flow of water in Doubtful Sound during plankton sampling (and hence the transport of Evechinus chloroticus larvae during SP1993/94), the wind conditions during the plankton samples from 27 January to 24 March 1994 (Fig. 7) can be examined. From the time of spawning (27 January) to the first plankton sampling (3 February), wind was 
constantly onshore (east direction). For the remainder of the sampling period that Evechinus larvae were recorded in the plankton ( 3 February to 15 March), wind blew offshore (west direction) for $83.9 \%$ of the time. As water tends to move up the fiord during periods of offshore winds (Fig. 7), it is likely that water was moving up the fiord during the majority of plankton sampling.

In light of these qualitative observations, and assuming that Evechinus chloroticus larvae behave as passive particles in the water column, the distribution of larvae can be interpreted. Firstly, the vertical distribution of larvae within Doubtful Sound may be correlated with the stratification of the water column. The lack of $E$. chloroticus larvae in the surface layers of Doubtful Sound is in contrast to most echinoid species previously examined (Rumrill et al. 1985, Emlet 1986, Pennington \& Emlet 1986, Pedrotti 1990, Sewell \& Watson 1993, Miller \& Emlet 1997) and would be expected since echinoid larvae are known to be sensitive to low salinities (Stickle \& Diehl 1987). In addition, the entrainment of near surface seawater by the outflowing LSL may cause an advection of larvae out of the fiord at these depths, resulting in lower larval densities. At greater depths there is probably a higher retention of larvae within the fiord, resulting in higher larval densities. Early stage E. chloroticus larvae are geonegative and/or photopositive when grown in culture (pers. obs.), and it is possible that in the absence of a LSL and a high rate of larval advection at shallower depths, larvae will occur nearer to the sea surface. Secondly, the slow movement of water into the fiord during periods of offshore winds likely results in the high level of larval retention observed. Larval numbers were consistently higher within the fiord during both SP1993/94 and SP1994/95, compared with the outer fiord site. During SP1993/94 for example, $4 \mathrm{wk}$ after spawning, larval densities within the fiord ranged from 65.3 to 461.0 larvae tow $w^{-1}$ compared to an average density of 2.0 larvae to ${ }^{-1}$ outside the fiord. The lower abundances of larvae at the outer-fiord site are probably due to the greater offshore advection and dispersal of larvae associated with coastal currents. A lower rate of larval retention within Doubtful Sound would be expected during periods of onshore winds. Thirdly, the counter-current flow up-fiord likely results in an advection of larvae to inner fiord sites. During SP1993/94, the numbers of larvae at the inner Hall Arm site increased over the 4 wk post-spawning period, with these increase in densities due to the transport of late-stage larvae into the area.

Two important consequences of the observed larval retention and reduced larval exchange are evident. Reduced larval exchange provides a mechanism for the genetic differentiation of the Doubtful Sound
Evechinus chloroticus population documented by Mladenov et al. (1997). Genetic differentiation of estuarine populations has been reported in invertebrate species, including Balanus improvisus (Furman et al. 1989) and Mytilus edulis (Côrte-Real et al. 1994). In both cases, reduced larval exchange has been cited as the probable cause of the differentiation. Reduced larval exchange will also influence recruitment processes, with E. chloroticus populations in Doubtful Sound being closed or semi-closed. This is probably in contrast to the majority of $E$. chloroticus populations which occur along open coast and are almost certainly open in terms of larval supply. Open marine invertebrate populations are more likely to have irregular and/or low recruitment (recruitment-limited), primarily due to a decoupling of reproduction and recruitment (Hughes 1990), and to the variability of larval supply associated with long range larval transport (Vance 1980,1984). Examples of recruitment limitation in open populations are given for a number of species (Roughgarden et al. 1985, Sutherland 1987, Hughes 1990, Karlson \& Levitan 1990). In contrast, closed invertebrate populations are likely to receive a regular supply of larvae, as in the asteroid Pisaster ochraceus (Sewell \& Watson 1993). Recruitment rates are high in Doubtful Sound compared with most E. chloroticus populations (Lamare 1997). The interpretation of these findings is that the variability in larval supply due to larval transport mechanisms is reduced in the Doubtful Sound population, resulting in higher recruitment. For more open populations, variable larval transport results in low recruitment. This hypothesis is supported by settlement collector data (Lamare 1997). Settlement rates in Doubtful Sound (a measure of larval supply) were greater and occurred over a longer period compared with settlement rates in another, open E. chloroticus population studied in Tory Channel, New Zealand.

Information on distributions and transport of Evechinus chloroticus larvae in Doubtful Sound suggests that this population has closed or semi-closed recruitment. Self-seeding populations such as in Doubtful Sound are rare among marine species with a relatively long-lived planktonic larval stage. Therefore, many issues relating to stock-recruitment relationships not adequately assessed in open populations could be addressed in Doubtful Sound and offer a better understanding of the dynamics of marine populations. Information of this nature is essential for the management of these populations in the face of increased harvest and anthropomorphic changes in habitat. Further examination of the larval biology of E. chloroticus in Doubtful Sound may also address wider questions on the influence that fiord environments can have on invertebrate larval distributions, population biology and genetic variability. 
Acknowledgements. Thanks to Paul Meredith, Clive Heseltine, Ewan Dickson (Fiordland Lobster Company), Daryl Coup, Paul Brewin and Nicole Goebel for technical assistance in the field, and to Mike Barker and John Jillett for help with the analysis of plankton samples. Andrew Shaw assisted with the analysis of S4 current meter data. This paper benefited from comments from Graham Allen, Mike Barker, Philip Mladenov, Steve Wing, Rachel Berquist and Brian Stewart Electricity Corporation, New Zealand provided data on the Manapouri Dam discharge rates. This study was funded by an Otago Research Grant provided by the University of Otago. New Zealand.

\section{LITERATURE CITED}

Aksnes DL, Aure J, Kaartvedt S, Magnesen T, Richard J (1989) Significance of advection for the carrying capacities of fjord populations. Mar Ecol Prog Ser 50:263-274

Bowman MJ, Dietrich DE (1995) The influence of the Manapouri Power Station on the circulation of Doubtful Sound: numerical model simulations. Report for Electricity Corporation New Zealand

Cameron RA, Rumrill SS (1982) Larval abundance and recruitment of the sand dollar Dendraster excentricus in Monterey Bay, California, USA. Mar Biol 71:197-202

Côrte-Real HBSN, Dixon DR, Holland PWH (1994) Introntargeted PCR: a new approach to survey neutral DNA polymorphism in bivalve populations. Mar Biol 120:407-414

Dix TG (1969) Larval life span of the echinoid Evechinus chloroticus (Val.). NZ J Mar Freshwat Res 3:13-16

Dix TG (1970a) Biology of Evechinus chloroticus (Echinoidea: Echinometridae) from different localities. 1. General. NZ J Mar Freshwat Res 4:91-116

Dix TG (1970b) Biology of Evechinus chloroticus (Echinoidea: Echinometridae) from different localities. 3. Reproduction. NZ J Mar Freshwat Res 4:385-405

Ebert TA, Russell MP (1988) Latitudinal variation in size structure of the west coast purple sea urchin: a correlation with headlands. Limnol Oceanogr 33:286-294

Ebert TA, Schroeter SC, Dixon JD, Kalvass P (1994) Settlement patterns of red and purple sea urchins (Strongylocentrotus franciscanus and $S$. purpuratus) in California, USA. Mar Ecol Prog Ser 111:41-52

Emlet RB (1986) Larval production, dispersal, and growth in a fiord: a case study on larvae of the sand dollar Dendraster excentricus. Mar Ecol Prog Ser 31:245-254

Epifanio CE, Little KT, Rowe PM (1988) Dispersal and recruitment of fiddler crab larvae in the Delaware River estuary. Mar Ecol Prog Ser 43:181-188

Fell HB (1960) Biological results of the Chatham Islands 1954 expedition. Part 2. Archibenthal and Iittoral echinoderms Bull NZ Dept Sci Ind Res 139:55-76

Furman ER, Yule AB, Crisp DJ (1989) Gene flow between populations of Balanus improvisus Darwin (Cirripedia) in British Estuaries. Scient Mar 53:465-472

Gage J (1972) A preliminary survey of the benthic macrofauna and sediments in Lochs Etive and Creran, sea-lochs along the west coast of Scotland. J Mar Biol Assoc UK 52 : $237-246$

Hernroth L (1987) Sampling and filtration efficiency of two commonly used plankton nets. A comparative study of the Nansen net and the UNESCO WP2 net. J Plankton Res 9: $719-728$

Hughes TP (1990) Recruitment limitation, mortality, and population regulation in open systems: a case study. Ecology $71: 12-20$
Kaartvedt S, Svendsen H (1995) Effect of freshwater discharge, intrusions of coastal water, and bathymetry on zooplankton distribution in a Norwegian fjord system. J Plankton Res 17:493-511

Karlson RH, Levitan DR (1990) Recruitment-limitation in open populations of Diadema antillarum: an evaluation. Oecologia 82:40-44

Ketchum BH (1983) Estuaries and enclosed seas. Elsevier Scientific Publications Company, Amsterdam

Kope RG, Botsford LW (1988) Detection of environmental influence on recruitment using abundance data. Can J Fish Aquat Sci 45:1448-1458

Lamare MD (1997) Population biology, pre-settlement processes and recruitment in the New Zealand sea urchin, Evechinus chloroticus Valenciennes (Echinoidea: Echinometridae). PhD thesis, University of Otago

Lamare MD, Stewart BG (1998) Mass spawning by the sea urchin Evechinus chloroticus (Echinodermata: Echinoidea) in a New Zealand fiord. Mar Biol 132:135-140

McRae A (1959) Evechinus chloroticus (Val.), an endemic New Zealand echinoid. Trans R Soc NZ 86:205-267

Miller BA, Emlet RB (1997) Influence of nearshore hydrodynamics on larval abundance and settlement of sea urchins Strongylocentrotus franciscanus and S. purpuratus in the Oregon upwelling zone. Mar Ecol Prog Ser 148:83-94

Mladenov PV, Allibone RM, Wallis GP (1997) Genetic differentiation in the New Zealand sea urchin Evechinus chloroticus (Echinodermata: Echinoidea). NZ J Mar Freshwat Res 31:261-269

Palumbi SR (1995) Using genetics as an indirect estimator of larval dispersal. In: McEdward L (ed) Ecology of marine invertebrate larvae. CRC Press, Boca Raton, p 369-387

Pawson DL (1965) New records of echinoderms from the Snares Islands to the south of New Zealand. Trans R Soc NZ 6:253-260

Pearson TH (1970) The benthic ecology of Loch Linnhe and Loch Eil, a sea-loch system on the west coast of Scotland. 1. The physical environment and distribution of the macrobenthic fauna. J Exp Mar Biol Ecol 5:1-34

Pedrotti ML (1990) Etude des processus biologiques et facteurs physiques responsables de la dispersion et du recrutement des larves méroplanctoniques. Modèle: les larves d'Echinodermes. Thèse de doctorat de l'Université Pierre et Marie Curie en Sciences de la Vie, Paris

Pedrotti ML. Fenaux L (1992) Dispersal of echinoderm larvae in a geographical area marked by upwelling (Ligurian Sea, NW Mediterranean). Mar Ecol Prog Ser 86:217-227

Pennington JT, Emlet RB (1986) Ontogenetic and diel vertical migration of a planktonic echinoid larva, Dendraster excentricus (Eschscholtz): occurrence, causes, and probable consequences. J Exp Mar Biol Ecol 104:69-95

Petersen JK, Svane I (1995) Larval dispersal in the ascidian Ciona intestinalis (L.). Evidence for a closed population. J Exp Mar Biol Ecol 186:89-102

Rasmussen E (1973) Systematics and ecology of the Isefjord marine fauna (Denmark). Ophelia 11:1-507

Roughgarden J, Iwasa Y, Baxter C (1985) Demographic theory for an open marine population with space-limited recruitment. Ecology 66:54-67

Rumrill SS, Pennington JT, Chia FS (1985) Differential susceptibility of marine invertebrate larvae: laboratory predation of sand dollar, Dendraster excentricus (Eschscholtz), embryos and larvae by zoeae of the red crab. Cancer productus Randall. J Exp Mar Biol Ecol 90:193-208

Scheltema RS (1986) On dispersal and planktonic larvae of benthic invertebrates: an eclectic overview and summary of problems. Bull Mar Sci 39:290-332 
Sewell MA, Watson JC (1993) A 'source' of asteroid larvae? recruitment of Pisaster ochraceus, Pycnopodia helianthoides and Dermasterias imbricata in Nootka Sound, British Columbia. Mar Biol 117:387-398

Shanks AL (1995) Mechanisms of cross-shelf dispersal of larval invertebrates and fish. In: McEdward L (ed) Ecology of marine invertebrate larvae. CRC Press, Boca Raton, p 323-368

Stickle WB, Diehl WJ (1987) Effects of salinity on echinoderms. In: Jangoux M, Lawrence JM (eds) Echinoderm studies 2. AA Balkema, Rotterdam, p 235-285

Strathmann RR (1974) The spread of sibling larvae of sedentary marine invertebrates. Am Nat 108:29-44

Strickland JDH, Parsons TR (1972) A practical handbook of seawater analysis. Bull Fish Res Bd Can 167

Sutherland JP (1987) Recruitment limitation in a tropical intertidal barnacle: Tetraclita panamensis (Pilsbry) on the Pacific coast of Costa Rica. J Exp Mar Biol Ecol 113: $267-282$

UNESCO (1968) Zooplankton sampling. Monographs on oceanographic methodology. UNESCO, Parls

Editorial responsibility: Otto Kinne (Editor),

Oldendorf/Luhe, Germany
Vance RR (1980) The effect of dispersal on population size in a temporally varying environment. Theor Popul Biol 18 $343-362$

Vance RR (1984) The effect of dispersal on population stability in one-species, discrete-space population growth models Am Nat 123:230-254

Walker MM (1982) Reproductive periodicity in Evechinus chloroticus in the Hauraki Gulf. NZ $J$ Mar Freshwat Res $16: 19-25$

Walker MM (1984) Larval life span, larval settlement, and early growth of Evechinus chloroticus (Valenciennes). NZ J Mar Freshwat Res 18:393-397

Wing SR, Largier JL, Botsford LW, Quinn JF (1995) Settlement and transport of benthic invertebrates in an intermittent upwelling region. Limnol Oceanogr 40:316-329

Young CM, Chia FS (1987) Abundance and distribution of pelagic larvae as influenced by predation, behaviour, and hydrographic factors. In: Giese AC, Pearse JS, Pearse VB (eds) Reproduction of marine invertebrates. Blackwell Scientific Publications, Palo A.lto, California, and The Box Wood Press, Pacific Grove, California, p 385-463

Submitted: September 25, 1997; Accepted: July 31, 1998

Proofs received from author(s): November 9, 1998 